\title{
The Effect of Leadership and Motivation on Organizational Commitment at PT. Indo Perkasa Indonesia in Tangerang
}

\author{
Priehadi Dhasa Eka \\ Universitas Pamulang \\ E-mail: dosen01577@unpam.ac.id
}

(Received: December-2017; Reviewed: January-2018; Accepted: February-2018;

Avalaibel Online: February-2018; Published: March-2018)

(c) (5) (5) This is an open access article distributed under the Creative Commons Attribution License EY CC-BY-NC-4.0 (C2018 by author (https://creativecommons.org/licenses/by-nc/4.0/)

\begin{abstract}
Leadership plays an important role because leaders will move different subordinates. The purpose of this study was to determine the effect of leadership and motivation on organizational commitment at PT. Indo Perkasa Indonesia in Tangerang. The method used in this research is descriptive with an associative approach, the sampling technique used is proportional random sampling using the census or saturated sampling method with a sample of 80 respondents. The analysis tool uses instrument testing, classical assumption testing, regression testing, determination coefficient testing and hypothesis testing. The results of the study concluded that there is a positive and significant influence both partially and simultaneously between leadership and motivation on organizational commitment with a contribution of 0.503 or $50.3 \%$ while the remaining $49.7 \%$ is influenced by other factors. Hypothesis testing obtained $F_{\text {count }}>F_{\text {table }}(38,975>2,720)$ thus $\mathrm{H} 0$ is rejected and $\mathrm{H} 3$ is accepted meaning that there is a positive and significant effect simultaneously between leadership and motivation on organizational commitment at PT. Indo Perkasa Indonesia in Tangerang.
\end{abstract}

Keywords: Leadership; motivation; organizational commitment.

\section{INTRODUCTION}

At a company, success or failure in the implementation of tasks is influenced by leadership, through leadership and good motivation will have an impact on good organizational commitment so that it can develop a better company (Barbuto, 2005; Pencheon, 2000; Sari, Muis, \& Hamid, 2012; Tucunan, Supartha, \& Riana, 2014, Sunarsi, 2017). Leadership plays an important role because it is the leader who will move different subordinates. In this case, leadership is an example to form a motivation and commitment in a company, because leadership will be an example of everything that is done for its employees (Sunarsi, 2016). Because the motivation and commitment of the company is very influential for the behavior of all employees, the commitment and motivation in the company is very influential to see every 
ability possessed by employees in the company and has a role in changing every strategy, vision and mission, and policies in the company (Indica, 2013; Sumarno, 2005; Widhi, Saputro Nugroho \& Setyawati, 2015). Through the right leadership system, it can lift a collapsed company or wait for time to stop operating to recover and improve its performance (Bangun, 2012). Not only does the leadership style affect the decline in employee performance, work discipline also has aspects that affect the decline in employee performance (Dapu, 2015; Rommy Beno Rumondor, Altje Tumbel, 2016; Tumilaar, 2015). Discipline is a matter of benchmark to find out whether the overall leadership role can be carried out properly or not. According to (Singodimedjo, 2009) discipline is an attitude of willingness and willingness to obey and obey the norms of regulations that apply around it. The low work ethic besides being related to the low quality of human resources can also be caused by lack of stimulation to increase the work enthusiasm of the personnel involved in activities (Dessler, 2015; Handoko, 2011; Priansa, 2014; Rahardi, 2010). Motivation in management is only aimed at human resources in general and in particular subordinates (Fitriyanto, 2005; Giantari \& Riana, 2017; Rismayadi \& Maemunah, 2016). The importance of work motivation is because it causes and supports human behavior so that they want to work actively and enthusiastically to achieve the desired results. To move people to match what the company wants, it must be understood the motivation of people who work at the company (Belle \& Cantarelli, 2017; Fariduddin, 2005; Locke \& Latham, 1990; Rumpak, 2014). Based on observations or pre-research conducted by the author on organizational commitment, it can be seen that organizational commitment is still not optimal as evidenced by a large number of employees with low attendance, completion of work that is not in accordance with the desired target, slow service, and low discipline. These conditions need to get the attention of the leadership so that organizational commitment will be better in the future. The basic thing that must be done by the leadership is the need to apply overall discipline from the lower levels to the leadership.

\section{METHOD}

The type of data used is quantitative with primary data sources by distributing questionnaires which are then tabulated and feasibility analysis and secondary data derived from the various scientific literature. The population in this study were employees of PT. Indo Perkasa Indonesia in Tangerang. Sampling was used saturation sampling technique that is 80 employees. The instrument testing uses validity and reliability tests. From the validity and reliability test stated valid and reliable, this is evidenced by the value of $r_{\text {count }}>r_{\text {table }}$, likewise, the instrument used is appropriate and feasible to be forwarded to the next test. Testing for normality using Kolmogorov Smirnov obtained significance of greater than 0.50 and thus declared normal. Multicollinearity testing obtained tolerance values $<1$ and VIF $<10$ so that it was concluded there was no interference with multicollinearity. Autocorrelation testing obtained Durbin-Watson values amounted to be in the interval 1.550-2.460, thus this regression model does not have autocorrelation. Heteroskesdastisitas testing with Glejser test obtained significance values greater than 0.05 so it was concluded that there was no interference with heteroscedasticity.

\section{RESULT AND DISCUSSION}


The criteria of the object under study are based on the respondent's response to the statement item. Leadership variable (X1) obtained an average score of 3.83 with a standard deviation of 43.1, a motivational variable (X2) of 3.82 with a standard deviation of 37.2 and an organizational commitment variable $(\mathrm{Y})$ of 3.92 with a standard deviation of 36,6 , all three variables obtained all scores are in the scale range of $3.40-4.19$ with good criteria.

\section{Multiple Linear Regression Analysis}

This regression test is intended to find out how much influence the dependent variable has on the dependent variable. The following results of the processed regression data can be seen in the following table:

Table 3

The Result of Multiple Regression Processing of Leadership Variable (X1) and Motivation (X3) Against Organizational Commitment (Y)

\begin{tabular}{|c|c|c|c|c|c|c|}
\hline \multicolumn{7}{|c|}{ Coefficients $^{a}$} \\
\hline \multirow{2}{*}{\multicolumn{2}{|c|}{ Model }} & \multicolumn{2}{|c|}{$\begin{array}{l}\text { Unstandardized } \\
\text { Coefficients }\end{array}$} & \multirow{2}{*}{$\begin{array}{c}\text { Standardized } \\
\text { Coefficients } \\
\text { Beta }\end{array}$} & \multirow[b]{2}{*}{$\mathrm{t}$} & \multirow[b]{2}{*}{ Sig. } \\
\hline & & $\mathrm{B}$ & Std. Error & & & \\
\hline 1 & (Constant) & 10.975 & 3.216 & & 3.412 & .001 \\
\hline & Leadership (X1) & .240 & .083 & .283 & 2.902 & .005 \\
\hline & Motivation (X2) & .497 & .095 & .510 & 5.232 & .000 \\
\hline
\end{tabular}

a. Dependent Variable: Organizational Commitment $(\mathrm{Y})$

Based on the results of the analysis of regression calculations in the above table, the regression equation $\mathrm{Y}=10.975+0.240 \mathrm{X} 1+0.497 \mathrm{X} 2 \mathrm{can}$ be obtained. From the above equation, it can be concluded that a constant value of 10.975 means that if the leadership variable (X1) and motivation (X2) do not exist then there is an organizational commitment value (Y) of 10.975 points. A value of $\mathrm{X} 10.240$ is interpreted if the constant is constant and there is no change in the motivational variable $(\mathrm{X} 2)$, then every 1 unit change in the leadership variable (X1) will result in a change in organizational commitment (Y) of 0.240 points. $\mathrm{X} 2$ value of 0.497 is interpreted if the constant is constant and there is no change in the leadership variable (X1), then every 1 unit change in the motivational variable (X2) will result in changes in organizational commitment (Y) of 0.497 points.

\section{Analysis of the Coefficient of Determination}

Analysis of the coefficient of determination is intended to determine the percentage strength of the relationship between the independent variables on the dependent variable both partially and simultaneously), in this study are the leadership variables (X1) and motivation (X2) on organizational commitment (Y). Here are the results of the calculation of the coefficient of determination whose test results are as follows:

Table 4

Results of Partial Determination Coefficient Analysis Between Leadership (X1) to Organizational Commitment (Y)

\section{Model Summary}

\begin{tabular}{ll|l|l|l} 
Model & $\mathrm{R}$ & $\mathrm{R}$ Square & Adjusted R Square & $\begin{array}{c}\text { Std. Error of the } \\
\text { Estimate }\end{array}$ \\
\hline
\end{tabular}




\begin{tabular}{|c|c|c|c|c|}
\hline 1 & $.571^{a}$ & 326 & & 3.024 \\
\hline
\end{tabular}

Based on the test results in the table above, the R-square value (determination coefficient) of 0.326 can be concluded that the leadership variable (X1) influences the organizational commitment variable (Y) by $32.6 \%$ while the remaining $67.4 \%$ is influenced by other factors.

Table 5

Results of Partial Determination Coefficient Analysis Between Motivation (X2) Against Organizational Commitment (Y)

\begin{tabular}{l|cr|rr|r} 
& \multicolumn{3}{c}{ Model Summary } \\
Model & $\mathrm{R}$ & R Square & \multicolumn{2}{c}{$\begin{array}{c}\text { Adjusted R } \\
\text { Square }\end{array}$} & \multicolumn{2}{c}{$\begin{array}{c}\text { Std. Error of the } \\
\text { Estimate }\end{array}$} \\
\hline 1 . & $.670^{\mathrm{a}}$ & .449 & .442 & 2.736 \\
\hline a. Predictors: (Constant), Motivation (X2) & & & &
\end{tabular}

Based on the test results in the above table, R-square value of 0.449 is obtained, it can be concluded that the motivation variable (X2) influences the organizational commitment variable (Y) by $55.1 \%$ while the remaining $55.1 \%$ is influenced by other factors.

Table 6

Results of Simultaneous Determination Coefficients of Simultaneous Leadership (X1) and Motivation (X2) Towards Organizational Commitment (Y)

\section{Model Summary}

\begin{tabular}{lrrrrr} 
Model & R & R Square & Adjusted R Square & Std. Error of the Estimate \\
\hline 1 & $.709^{a}$ & .503 & .490 & 2.614 \\
\hline a. Predictors: (Constant), Motivation (X2), Leadership (X1) & &
\end{tabular}

Based on the test results in the table above, an R-square value of 0.503 can be concluded that the leadership (X1) and motivation (X2) variables influence the organizational commitment variable $(\mathrm{Y})$ by $50.3 \%$ while the remaining $49.7 \%$ influenced by other factors that were not conducted research.

\section{Hypotesis Test}

Hypothesis testing of leadership variables (X1) and motivation (X2) on organizational commitment $(\mathrm{Y})$ is done by t-test (partial test). In this study the significance criteria used 5\% $(0.05)$ with the following results:

Table 7

Hypothesis Test Results (t-Test) Leadership Variable (X1) Against Organizational Commitment (Y)

\section{Coefficients $^{a}$}

Unstandardized

Coefficients

\begin{tabular}{|c|c|c|c|c|c|c|}
\hline \multirow{2}{*}{\multicolumn{2}{|c|}{ Model }} & \multicolumn{2}{|c|}{ Coefficients } & \multirow{2}{*}{$\begin{array}{c}\text { Coefficients } \\
\text { Beta }\end{array}$} & \multirow[b]{2}{*}{$\mathrm{t}$} & \multirow[b]{2}{*}{ Sig. } \\
\hline & & $\mathrm{B}$ & Std. Error & & & \\
\hline 1 & (Constant) & 20.667 & 3.041 & & 6.795 & .000 \\
\hline & Leadership (X1) & 486 & .079 & .571 & 6.148 & .000 \\
\hline
\end{tabular}


a. Dependent Variable: Organizational Commitment( $(\mathrm{Y})$

Based on the test results in the above table, the value of $t$ count $>t$ table or $(6.148>1.991)$ is also strengthened by the value of $\rho$ value $<$ Sig. 0.05 or $(0.000<0.05)$. Thus, $\mathrm{H} 0$ is rejected and $\mathrm{H} 1$ is accepted, this shows that there is a positive and partially significant effect between motivation on organizational commitment at PT. Indo Perkasa Indonesia in Tangerang.

Table 8

Hypothesis Test Results (t-Test) Motivation (X2) on Organizational Commitment (Y)

\begin{tabular}{|c|c|c|c|c|c|c|}
\hline \multirow{2}{*}{\multicolumn{2}{|c|}{ Model }} & \multicolumn{2}{|c|}{ Unstandardized Coefficients } & \multirow{2}{*}{$\begin{array}{c}\text { Standardized } \\
\text { Coefficients } \\
\text { Beta }\end{array}$} & \multirow[b]{2}{*}{$\mathrm{t}$} & \multirow[b]{2}{*}{ Siq. } \\
\hline & & B & Std. Error & & & \\
\hline 1 & (Constant) & 14.182 & 3.161 & & 4.487 & .000 \\
\hline & Motivation (X2) & .654 & .082 & .670 & 7.968 & .000 \\
\hline
\end{tabular}

a. Dependent Variable: Organizational Commitment (Y)

Based on the test results in the table above we get the value of $t_{\text {count }}>t_{\text {table }}$ or $(7.968>1.991)$. This was also reinforced by the value of $\rho$ value $<$ Sig. 0.05 or $(0,000<0.05)$. Thus, H0 is rejected and $\mathrm{H} 2$ is accepted, this shows that there is a positive and partially significant effect between motivation on organizational commitment at PT. Indo Perkasa Indonesia in Tangerang. To test the effect of motivation and motivation variables simultaneously on organizational commitment at PT. Indo Perkasa Indonesia in Tangerang was carried out with an F statistical test (simultaneous test) with a significance of 5\%. In this study, the significance criteria used $5 \%(0.05)$. The test results are as follows:

Table 9.

Hypothesis Results (F Test) Simultaneously Leadership (X1) and Motivation (X2) Towards Organizational Commitment (Y)

\begin{tabular}{|c|c|c|c|c|c|c|}
\hline \multicolumn{7}{|c|}{ ANOVA $^{a}$} \\
\hline \multicolumn{2}{|c|}{ Model } & Sum of Squares & df & Mean Square & $\mathrm{F}$ & Sig. \\
\hline 1 & Regression & 532.748 & 2 & 266.374 & 38.975 & $.000^{\mathrm{b}}$ \\
\hline & Residual & 526.252 & 77 & 6.834 & & \\
\hline & Total & 1059.000 & 79 & & & \\
\hline
\end{tabular}

a. Dependent Variable: Organizational Commitment (Y)

b. Predictors: (Constant), Motivation (X2), Leadership (X1)

Based on the test results in the above table, the calculated $F_{\text {count }}>F_{\text {table }}$ or $(38.975>2.720)$ is also strengthened by the $\rho$ value $<$ Sig. 0.05 or $(0,000<0.05)$. Thus, H0 is rejected and H3 is accepted, this shows that there is a positive and significant simultaneous effect between motivation and motivation on organizational commitment at PT. Indo Perkasa Indonesia in Tangerang. 


\section{CONCLUSION}

Based on the research results obtained that Leadership (X1) has a positive and significant effect on organizational commitment (Y) with a coefficient of determination of $32.6 \%$. Motivation (X2) has a positive and significant effect on organizational commitment (Y) with a coefficient of determination of 44.9\%. Leadership (X1) and motivation (X2) have a positive and significant effect on organizational commitment $(\mathrm{Y})$ with a regression equation $\mathrm{Y}=10.975+$ $0.240 \mathrm{X} 1+0.497 \mathrm{X} 2$. The coefficient of determination or influence simultaneously is $50.3 \%$ while the remaining $49.7 \%$ is influenced by other factors. Hypothesis testing obtained the value of $F_{\text {count }}>F_{\text {table }}$ or $(38.975>2.720$ ), this was also strengthened by a probability of significance of $0,000<0.05$. Thus $\mathrm{H} 0$ is rejected and $\mathrm{H} 3$ is accepted. This means that there is a positive and significant effect simultaneously between motivation and motivation on organizational commitment at PT. Indo Perkasa Indonesia in Tangerang.

\section{REFERENCES}

Bangun, W. (2012). Manajemen Sumber Daya Manusia. Manajemen Sumber Daya Manusia.

Barbuto, J. E. (2005). Motivation and Transactional, Charismatic, and Transformational Leadership: A Test of Antecedents. Journal of Leadership \& Organizational Studies. https://doi.org/10.1177/107179190501100403

Belle, N., \& Cantarelli, P. (2017). Work motivation. In Experiments in Public Management Research: Challenges and Contributions. https://doi.org/10.1017/9781316676912.009

Dapu. (2015). the Influence of Work Discipline, Leadership, and Motivation on Employee Performance At Pt. Trakindo Utama Manado. Jurnal Riset Ekonomi, Manajemen, Bisnis dan Akuntansi.

Dessler, G. (2015). Manajemen Sumber Daya Manusia. In Jakarta: Salemba Empat.

Fariduddin, S. (2005). The Motivation to Work. Journal of Independent Studies and ResearchManagement, Social Sciences and Economics. https://doi.org/10.31384/jisrmsse/2005.03.1.4

Fitriyanto. (2005). Pengaruh Motivasi Kerja dan Pengalaman Kerja terhadap Produktivitas Kerja. Pengaruh Motivasi Kerja dan Pengalaman Kerja terhadap Produktivitas Kerja.

Giantari, I. A. I., \& Riana, I. G. (2017). Pengaruh Budaya Organisasi Terhadap Motivasi Kerja Dan Kinerja Karyawan Klumpu Bali Resort Sanur. E-Jurnal Manajemen Unud, ISSN 2302-8912.

Handoko, T. H. (2011). Manajemen Personalia dan Sumber Daya Manusia. Pengantar Manajemen.

Indica, I. (2013). Pengaruh Etos Kerja Islami Dan Gaya Kepemimpinan Transformasional Terhadap Komitmen Organisasional Dan Kinerja Karyawan. Jurnal Ilmiah Mahasiswa FEB.

Locke, E. A., \& Latham, G. P. (1990). Work Motivation and Satisfaction: Light at the End of 
the Tunnel. Psychological Science. https://doi.org/10.1111/j.1467-9280.1990.tb00207.x

Pencheon, D. (2000). Leadership and motivation. BMJ. https://doi.org/10.1136/bmj.321.7256.S2-7256

Priansa, D. J. (2014). Perencanaan dan Pengembangan Sumber Daya Manusia. In 200. https://doi.org/10.1039/c5cc07884a

Rahardi, D. R. (2010). Manajemen Kinerja Sumber Daya Manusia. In Applied Physics A: Materials Science and Processing. https://doi.org/10.1007/s00339-002-1913-7

Rismayadi, B., \& Maemunah, M. (2016). Pengaruh Motivasi Kerja, Kepemimpinan dan Budaya Organisasi Terhadap Kepuasan Kerja Karyawan serta Dampaknya pada Kinerja Perusahaan (Studi kasus pada PT. Concord Indonesia). Jurnal Manajemen \& Bisnis Kreatif. https://doi.org/10.36805/manajemen.v2i1.181

Rommy Beno Rumondor, Altje Tumbel, J. L. S. 2016. (2016). Pengaruh Kepemimpinan, Motivasi, dan Disiplin Kerja terhadap Kinerja Pegawai pada Kanwil Ditjen Kekayaan Negara Suluttenggomalut. Emba.

Rumpak, A. D. (2014). Pengaruh Motivasi Kerja Terhadap Kinerja Karyawan Pada Bank Indonesia Institute. Jurnal Motivasi Penilaian Kinerja.

Sari, R., Muis, M., \& Hamid, N. (2012). Pengaruh Kepemimpinan, Motivasi, Dan Stres Kerja Terhadap Kinerja Karyawan Pada Bank Syariah Mandiri Kantor Cabang Makassar. Jurnal Analisis.

Singodimedjo. (2009). Manajemen Sumber Daya Manusia. In Manajemen Sumber Daya Manusia.

Sumarno, J. (2005). Pengaruh Komitmen Organisasi dan Gaya Kepemimpinan Terhadap Hubungan Antara Partisipasi Anggaran dan kinerja Manajerial. Jurnal Bisnis Strategi.

Sunarsi, D (2016). Pengaruh Minat, Motivasi Dan Kecerdasan Kognitif Terhadap Prestasi Belajar (Studi Kasus Pada Mahasiswa Program Studi S-1 Manajemen. Fakultas Ekonomi. Universitas Pamulang. Thn. Akademik 2015-2016). In Proceedings (Vol. 1, No. 1).

Sunarsi, D. (2017). Pengaruh Disiplin, Motivasi, Dan Kompetensi Terhadap Prestasi Belajar (Studi Kasus Pada Mahasiswa Universitas Pamulang, Tangerang Selatan Tahun Akademik 2016-2017). Jurnal Mandiri: Ilmu Pengetahuan, Seni, Dan Teknologi, 1(2), 207-226.

Tucunan, R. J. A., Supartha, W. G., \& Riana, I. G. (2014). Pengaruh Kepemimpinan Transformasional terhadap Motivasi dan Kinerja Karyawan Sudi Kasus Pada PT. Pandawa. E-Jurnal Ekonomi dan Bisnis Universitas Udayana.

Tumilaar, B. R. (2015). the Effect of Discipline, Leadership, and Motivation on Employee Performance At Bpjs Ketenagakerjaan Sulut. Jurnal Riset Ekonomi, Manajemen, Bisnis dan Akuntansi.

Widhi, Saputro Nugroho \& Setyawati, E. (2015). Pengaruh Independensi, Gaya Kepemimpinan, Komitmen Organisasi dan Pemahaman Good Governance terhadap Kinerja Auditor Pemerintah. Benefit: Jurnal Manajemen dan Bisnis. 
80 Pinisi Discretion Review

Volume 1, Issue 2, March, 2018 Page. 73- 8o 
Priehadi Dhasa Eka; The Effect of Leadership and Motivation on Organizational Commitment ...|81 